\title{
Hubungan Antara Riwayat Pemberian Imunisasi dan Penyakit Infeksi dengan Status Gizi pada Anak Usia 24-59 Bulan di Kecamatan Ratahan Kabupaten Minahasa Tenggara. \\ (Relationship Between History of Immunization and Infectious Disease with Nutritional Status in Children aged 24-59 Months in Ratahan Subdistrict, Southeast Minahasa Regency)
}

\author{
Elshaday Kasim ${ }^{1) *}$, Nancy Malonda ${ }^{1}$, Marsella Amisi ${ }^{1)}$ \\ ${ }^{*}$ Fakultas Kesehatan Masyarakat Universitas Sam Ratulangi, Manado 95115 \\ *Email korespondensi:enkasim96@gmail.com
}

Diterima 15 Februari 2019, diterima untuk dipublikasi 28 Februari 2019

\begin{abstract}
ABSTRAK
Riwayat pemberian imunisasi dan penyakit infeksi erat kaitannya dengan pertumbuhan dan perkembangan anak berusia di bawah lima tahun. Penelitian ini bertujuan untuk menganalisis hubungan antara riwayat pemberian imunisasi dan penyakit infeksi dengan status gizi pada anak usia 24-59 bulan di Kecamatan Ratahan Kabupaten Minahasa Tenggara. Metode observasional analitik dengan rancangan penelitian cross sectional study. Penelitian ini adalah anak usia 24-59 bulan dengan jumlah 447 balita, teknik pengambilan sampel yaitu simple random sampling dengan penentuan jumlah sampel dilakukan dengan cara perhitungan menggunakan rumus slovin sehingga jumlah sampel yang diambil yaitu 88 sampel. Riwayat pemberian imunisasi, penyakit infeksi dan status gizi diukur menggunakan kuesioner dan pengukuran antropometri dengan alat timbangan untuk mengukur berat badan, serta microtoise untuk mengukur tinggi badan, kemudian menghitung z-score. Berdasarkan hasil uji chi square mendapati tidak adanya hubungan antara riwayat pemberian imunisasi dengan status gizi menurut indeks antropometri TB/U, $B B / U, B B / T B$ dan tidak adanya hubungan antara penyakit infeksi dengan status gizi menurut $T B / U, B B / U$ dan $B B / T B$.
\end{abstract}

Kata Kunci : Imunisasi, penyakit infeksi, status gizi. Kabupaten Minahasa

Tenggara.

\begin{abstract}
History of Immunization and Infectious Disease is a factor that is very closely related to the growth and development of children under the age of five. This study aims to determine the relationship between the History of Immunization and Infectious Disease with Nutritional Status in Children aged 24-59 Months in Ratahan Subdistrict, Southeast Minahasa Regency. Analytical observational method with cross sectional study design. This study is a child aged 24-59 months with a total of 447 toddlers, the sampling technique is simple random sampling by determining the number of samples carried out by calculation using the slovin formula so that the number of samples taken is 88 samples. History of immunization, infectious disease and nutritional status was measured using a questionnaire and anthropometric measurements with a scale tool to measure weight, and microtoise to measure height, then calculate the z-score. Based on the results of the chi square test, there was no correlation between the history of immunization and nutritional status according to the anthropometric index $T B$ / $U$, $B B / U, B B / T B$ and the absence of an association between infectious diseases and nutritional status according to TB / U, BB / $U$ and BB / TB.

Keywords: Immunization, infectious disease, nutritional status, Southeast Minahasa Regency
\end{abstract}

\section{PENDAHULUAN}

Masalah Status Gizi kurang mempengaruhi kualitas generasi selanjutnya. Generasi mendatang yang baik dapat di tentukan dari kualitas balita yang baik pula. Oleh sebab itu harus dilakukan pengawasan kepada status gizi balita supaya dapat 
mengurangi masalah gizi (Susiloningrum 2017).

Menurut hasil Riset Kesehatan Dasar (Riskesdas), di Indonesia jumlah anak yang menderita gizi kurang tahun 2007 pada umur dibawah 5 tahun adalah 36,8\%. Pada tahun 2010 mengalami penurunan menjadi $35,6 \%$, tahun 2013 terjadi penurunan sebesar $3,2 \%$. Presentasi gizi kurang di Sulawesi Utara pada tahun 2015 yang di peroleh dari pemantauan status gizi oleh Kementrian Kesehatan yaitu 15,9\% pendek dan $6,3 \%$ sangat pendek. World Health Organization (WHO) mengatakan bahwa sampai pada tahun 2017 terdapat kurang lebih 178 juta anakanak yang berumur dibawah 5 tahun mengalami gizi kurang .Pola asuh, ketersediaan pangan sanitasi lingkungan, dan pelayanan kesehatan yang meliputi akses imunisasi dapat menyebabkan stunting. Lambatnya pertumbuhan anak dan imunitas yang masih rendah, serta menurunnya prestasi belajar, mengganggu produktifitas merupakan akibat dari status gizi. Kemiskinan serta masalah gizi menjadi poin satu dan dua dalam Sustainable Development Goals (SDGs) (Riskesdas 2013).

Hasil Riset Kesehatan Dasar tahun 2013 menunjukan bahwa di Sulawesi Utara prevalensi status gizi balita sangat pendek sebesar $17 \%$ dan balita yang pendek sebesar $17,8 \%$. Di Kabupaten Minahasa Tenggara menunjukkan bahwa prevalensi balita sangat pendek masih terbilang tinggi yaitu sebesar $20,9 \%$ dan prevalensi balita pendek sebesar 20,9\% hal ini menyatakan bahwa jumlah balita yang sangat pendek dan pendek di Minahasa Tenggara lebih tinggi dibandingkan prevalensi di Sulawesi utara (Suharmiati et al. 2013).

Masalah yang berkaitan perkembangan gizi masih sangat kompleks ditemui di Indonesia. Masalah mengenai kurang gizi perlu diperhatikan serta perlu untuk ditangani serius, berbagai upaya yang dilakukan untuk menanggulangi masalah stunting dengan prioritas untuk menurunkan angka kejadian gizi kurang menjadi 32\% (Kemenkes RI, 2015). Faktor yang mempengaruhi status gizi pada anak balita adalah pemberian imunisasi dan penyakit infeksi (Aridiyah et al. 2015). Sejak tahun 1956 di Indonesia telah melaksanakan program imunisasi sebagai upaya dalam mengurangi kasus penyakit yang biasa dicegah oleh imunisasi. Imunisasi menjadi salah satu upaya investasi kesehatan yang murah dilakukan dalam mencegah penyakit. Salah satu program yang menjadi prioritas pembangunan kesehatan tahun 2015-2019 yaitu penurunan prevalensi balita pendek yaitu dengan meningkatkan status gizi dari masyarakat. Salah satu upaya yang dilakukan dalam mengintervensi kejadian stunting pada balita yaitu dengan imunisasi dasar yang lengkap (Kemenkes RI 2016).

Hasil riset kesehatan dasar tahun 2013 mengenai cakupan imunisasi lengkap meningkat dari tahun 2007 sampai 2013 yaitu dari 41,6\% ditahun 2007 meningkat menjadi 59,2\% akan tetapi ditahun 2013 terdapat 32,1\% balita yang belum diimunisasi lengkap dan masih ada sebanyak $8,7 \%$ balita yang belum diberikan imunisasi. Pada tingkat provinsi , Sulawesi Utara dengan tingkat prevalensi pencapaian imunisasi sebesar 79,09 yang belum memenuhi target WHO 90\%. (Ditjen PPPL, Kemenkes RI 2013). Berdasarkan dengan data Puskesmas Ratahan, bayi yang mendapatkan imunisasi dasar berjumlah 1041 bayi (Anonim 2016'1). Pemberian Imunisasi berupaya untuk menurunkan kejadian penyakit yang bias dicegah melalui pemberian imunisasi. Penyakit infeksi yang sering menyerang anak yaitu infeksi pernafasan ISPA dan pencernaan Diare. Penyakit infeksi terutama infeksi pernafasan dan pencernaan merupakan penyebab kematian terbesar pada anak di negara berkembang termasuk Indonesia (Gerungan 2014). Kasus di Indonesia pada tahun 2016, jumlah anak balita yang mengalami diare 
$36,9 \%$ dan di Sulawesi Utara terdapat 9,7\% mengalami diare. Kasus ISPA yang di dapati di Indonesia berjumlah $503,738 \%$ dan di Sulawesi Utara terdapat 55,9\% mengalami ISPA (Kemenkes RI 2017). Penelitian ini bertujuan untuk menganalisis hubungan antara riwayat pemberian imunisasi dan penyakit infeksi dengan status gizi pada anak usia 24-59 bulan di Kecamatan Ratahan Kabupaten Minahasa Tenggara.

\section{METODE PENELITIAN}

Penelitian ini dilaksanakan di Kecamatan Ratahan Kabupaten Minahasa Tenggara. Kecamatan Ratahan terdiri dari 2 desa dan 9 kelurahan yaitu, Desa Rasi, Desa Rasi Satu, Kelurahan Nataan, Kelurahan Lowu I, Kelurahan Lowu II, Kelurahan Lowu Utara, Kelurahan Tosuraya, Kelurahan Tosuraya Selatan, Kelurahan Tosuraya Barat, Kelurahan Wawali, Kelurahan Wawali Pasan

Desain menggunakan deskriptif analitik dengan metode cross sectinal study. Sampel dalam penelitian ini berjumlah 88 responden yang diperoleh secara simple random sampling. Instrumen penelitian yang digunakan yaitu kuesioner mengenai riwayat pemberian imunisasi dan penyakit infeksi, microtois untuk mengukur tinggi badan balita dengan ketelitian $0,1 \mathrm{~cm}$, dan timbangan untuk menimbang berat badan. Analisis data menggunakan analisis univariat dan bivariat menggunakaan uji chi square dengan $a=0,05$.

\section{HASIL PENELITIAN \\ Analisis Univariat}

Karakteristik umum berjumlah 88 sampel. Berdasarkan jenis kelamin, yaitu 40 sampel berjenis kelamin perempuan dan 48 sampel berjenis kelamin laki-laki, sampel laki-laki lebih banyak dari pada sampel perempuan. Karakteristik sampel berdasarkan umur yaitu kelompok umur 24-35 bulan berjumlah 29 sampel, umur 36-47 bulan berjumlah 30 sampel dan umur 48-59 bulan berjumlah 29 sampel. Responden dalam penelitian ini yaitu ibu kandung dari sampel. Umur ibu dibagi menjadi tiga kategori mulai dari 17-28 tahun berjumlah 34 responden, 29-40 tahun berjumlah 35 responden dan 41-53 tahun berjumlah 19 responden (Tabel 1)

Tabel 1. Karakteristik umum jenis kelamin dan umur

\begin{tabular}{lcc}
\hline \multicolumn{1}{c}{ Karakteristik } & $\mathrm{N}$ & $\%$ \\
\hline $\begin{array}{l}\text { Jenis Kelamin Sampel } \\
\text { Perempuan } \\
\text { Laki-laki }\end{array}$ & & \\
& 40 & 45,5 \\
Umur & 48 & 54,5 \\
1. Sampel (bulan) & & \\
a. 24-35 & 29 & 33 \\
b. 36-47 & 30 & 34 \\
c. 48-59 & 29 & 33 \\
2bu (tahun) & & \\
a. 17-28 & 34 & 38,6 \\
b. 29-40 & 35 & 39,8 \\
c. $41-53$ & 19 & 21,6 \\
\hline
\end{tabular}

Pendidikan ibu paling banyak yaitu berpendidikan SMA dengan jumlah 47 responden, berpendidikan SMP dengan jumlah 23 respnden, berpendidikan SD dengan jumlah 6 responden, berpendidikan $S 1$ dengan jumlah 7 responden, berpendidikan diploma dengan jumlah 4 responden, dan yang paling kurang tidak tamat SD dengan jumlah 1 responden (Tabel 2).

Status gizi sampel berdasarkan indeks antropometri Berat Badan Menurut Umur (BB/U) yaitu sebesar $20.5 \%$ yang mengalami status gizi kurang dan $79.5 \%$ mengalmi status gizi baik. Gambaran status gizi sampel menurut Tinggi Badan berdasarkan Umur (TB/U) sebesar $38.6 \%$ mengalami status gizi pendek dan $61.4 \%$ memiliki status gizi yang normal. Gambaran status gizi sampel berdasarkan Berat Badan Menurut Tinggi Badan yaitu 6.8\% memiliki status gizi yang kurus dan $93.2 \%$ memiliki status gizi yang normal (Tabel 3). 
Tabel 2. Karakteristik umum pendidikan ibu dan pekerjaan ibu

\begin{tabular}{lcc}
\hline \multicolumn{1}{c}{ Karakteristik } & N & $\%$ \\
\hline Pendidikan Ibu & & \\
Tidak Tamat SD & 1 & 1,1 \\
SD & 6 & 6,8 \\
SMP & 23 & 26,1 \\
SMA & 47 & 53,4 \\
D1/DII/DIII & 4 & 4,5 \\
S1 & 7 & 8 \\
Pekerjaan Ibu & & \\
IRT & 69 & 78,4 \\
PNS & 7 & 8,0 \\
Pegawai Honorer & 2 & 2,3 \\
Pegawai Swasta & 6 & 6,8 \\
Wiraswasta & 4 & 4,5 \\
\hline
\end{tabular}

Tabel 3. Gambaran status gizi

\begin{tabular}{llcc}
\hline & Status Gizi & $\mathrm{N}$ & $\%$ \\
\hline \multirow{2}{*}{ BB/ } & Gizi buruk & 0 & 0 \\
$\mathrm{U}$ & Gizi Kurang & 18 & 20,5 \\
& Gizi Baik & 70 & 79,5 \\
& Gizi Lebih & 0 & 0 \\
\hline \multirow{2}{*}{ TB/ } & Sangat Pendek & 0 & 0 \\
$\mathrm{U}$ & Pendek & 34 & 38,6 \\
& Normal & 54 & 61,4 \\
& Tinggi & 0 & 0 \\
\hline \multirow{2}{*}{ BB/ } & Sangat Kurus & 0 & 0 \\
TB & Kurus & 6 & 6.8 \\
& Baik & 82 & 93,2 \\
& Gemuk & 0 & 0 \\
\hline
\end{tabular}

Riwayat pemberian imunisasi balita yang mendapatkan imunisasi lengkap berjumlah 84 (95.5\%) balita dan $4(4.5 \%)$ balita belum diberikan imunisasi dasar lengkap. Balita yang memiliki imunisasi BCG sebanyak 87 $(98.9 \%)$ dan 1 (1.1\%) balita yang belum diberikan imunisasi BCG. Balita yang memiliki imunisasi DPT sebesar 87 $(98.9 \%)$ dan $1(1.1 \%)$ balita yang belum memiliki imunisasi DPT. Semua balita mendapatkan imunisasi polio. Balita yang diberikan imunisasi campak sebanyak 85 (96.6\%) dan 3 (3.4\%) balita belum dibrikan imunisasi campak. Balita yang mendapatkan imunisasi hepatitis berjumlah 87 (98.9\%) dan 1 $(1.1 \%)$ balita tidak mendapat imunisasi hepatitis (Tabel 4)

Tabel 4. Gambaran riwayat pemberian imunisasi pada balita

\begin{tabular}{lccc}
\hline Variabel & & $\mathrm{N}$ & $\%$ \\
\hline \multirow{3}{*}{ Imunisasi } & Lengkap & 84 & 95,5 \\
& Tidak & & \\
& Lengkap & 4 & 4,5 \\
BCG & Ya & 87 & 98,9 \\
& Tidak & 1 & 1,1 \\
DPT & Ya & 87 & 98,9 \\
& Tidak & 1 & 1,1 \\
Polio & Ya & 88 & 100,0 \\
& Tidak & 0 & 0 \\
Campak & Ya & 85 & 96,6 \\
& Tidak & 3 & 3,4 \\
Hepatitis & Ya & 87 & 98,9 \\
& Tidak & 1 & 1,1 \\
\hline
\end{tabular}

Gambaran penyakit infeksi pada balita yang mengalami penyakit infeksi berjumlah $26(29,5 \%)$ dan 62 (70,5\%) tidak mengalami penyakit infeks (Tabel 5).

Tabel 5. Gambaran penyakit infeksi pada balita

\begin{tabular}{cccc}
\hline Variabel & & $\mathrm{N}$ & $\%$ \\
\hline \multirow{2}{*}{ Penyakit Infeksi } & Ya & 26 & 29,5 \\
& Tidak & 62 & 70,5 \\
\hline
\end{tabular}

\section{Analisis Bivariat}

Status gizi balita menurut BB/ $U$ yang mempunyai status gizi kurang sebanyak 18 (20.5\%) balita. Bagi balita yang mempunyai status gizi kurang dan diberikan imunisasi lengkap sebanyak $17(19.3 \%)$, sebanyak $1(1.1 \%)$ balita yang mempunyai status gizi kurang yang belum mendapatkan imunisasi dasar lengkap. Status gizi baik pada balita sebanyak 70 (79.5\%). Bagi balita yang mempunyai status gizi baik yang telah diberikan imunisasi lengkap 67 (76.1\%), sebanyak $3(3.4 \%)$ balita yang mempunyai status gizi baik akan tetapi belum mendapatkan imunisasi lengkap. Berdasarkan hasil penelitian ini mendapati $p$ value $=1000$, sehingga 
penelitian ini menyatakan bahwa tidak adanya hubungan antara riwayat pemberian imunisasi dengan status gizi berdasarkan BB/U (Tabel 6).

Tabel 6. Hubungan riwayat pemberian imunisasi dengan status gizi balitaberdasarkan BB/U

\begin{tabular}{|c|c|c|c|c|c|c|c|}
\hline \multirow{3}{*}{$\begin{array}{l}\text { Imuni- } \\
\text { sasi }\end{array}$} & \multicolumn{4}{|c|}{$\begin{array}{c}\text { Status gizi balita } \\
\text { BB/U }\end{array}$} & \multirow{2}{*}{\multicolumn{2}{|c|}{ Total }} & \multirow{3}{*}{$\begin{array}{c}p \\
\text { value }\end{array}$} \\
\hline & \multicolumn{2}{|c|}{$\begin{array}{c}\text { Gizi } \\
\text { Kurang }\end{array}$} & \multicolumn{2}{|c|}{ Gizi Baik } & & & \\
\hline & $\mathrm{N}$ & $\%$ & $\mathrm{~N}$ & $\%$ & $\mathrm{~N}$ & $\%$ & \\
\hline $\begin{array}{l}\text { Tidak } \\
\text { Lengkap }\end{array}$ & 1 & 1.1 & 3 & 3.4 & 4 & 4.5 & 1.000 \\
\hline Lengkap & 17 & 19.3 & 67 & 76.1 & 84 & 95.1 & \\
\hline Total & 18 & 20.5 & 70 & 79.5 & 8 & 100.0 & \\
\hline
\end{tabular}

${ }^{*}$ Fisher's Exact Test

Status gizi balita menurut TB/U yang mempunyai status gizi pendek sebanyak 34 (38.6\%) balita. Bagi balita yang mempunyai status gizi pendek dan diberikan imunisasi lengkap sebanyak $32(36.4 \%)$ dan 2 (2.3\%) balita yang mendapatkan status gizi pendek yang tidak diberikan imunisasi lengkap. Status gizi balita yang normal 54 (61.4\%). Bagi balita yang mempunyai status gizi normal dan diberikan imunisasi lengkap sebesar 52 (59.1\%) dan $2(2.3 \%)$ balita yang mempunyai status gizi normal yang tidak diberikan imunisasi lengkap. Berdasarkan hasil penelitian ini mendapati bahwa $p$ value $=0.638$, sehingga dari penelitian ini menyatakan bahwa tidak ditemukan hubungan antara riwayat pemberian imunisasi dengan status gizi berdasarkan TB/U (Tabel 7).

Status gizi balita menurut BB/TB yang mempunyai status gizi yang kurus sebanyak $6(6.8 \%)$ balita. Bagi balita yang mempunyai status gizi yang kurus yang memiliki imunisasi lengkap 6 $(6.8 \%)$ dan tidak didapati balita yang mempunyai status gizi kurus yang tidak diberikan imunisasi yang lengkap. Status gizi balita yang normal sebanyak $82(93.2 \%)$. Bagi balita yang mempunyai status gizi normal dan diberikan imunisasi lengkap sebesar 78 (88.6\%), $4(4.5 \%)$ balita yang mempunyai status gizi yang normal dan tidak diberikan imunisasi yang lengkap. Berdasarkan hasil penelitian ini menyatakan bahwa $p$ value $=1000$, sehingga dari penelitian ini menyatakan bahwa tidak adanya hubungan antara riwayat pemberian imunisasi dengan status gizi berdasarkan BB/TB (Tabel 8).

Tabel 7. Hubungan riwayat pemberian imunisasi dengan status gizi balita berdasarkan TB/U

\begin{tabular}{|c|c|c|c|c|c|c|c|}
\hline \multirow{3}{*}{$\begin{array}{l}\text { Imuni- } \\
\text { sasi }\end{array}$} & \multicolumn{4}{|c|}{$\begin{array}{c}\text { Status gizi balita } \\
\mathrm{TB} / \mathrm{U}\end{array}$} & \multirow{2}{*}{\multicolumn{2}{|c|}{ Total }} & \multirow{3}{*}{$\begin{array}{c}p \\
\text { value }\end{array}$} \\
\hline & \multicolumn{2}{|c|}{ Pendek } & \multicolumn{2}{|c|}{ Normal } & & & \\
\hline & $\mathrm{N}$ & $\%$ & $\mathrm{~N}$ & $\%$ & $\mathrm{~N}$ & $\%$ & \\
\hline $\begin{array}{l}\text { Tidak } \\
\text { Lengkap }\end{array}$ & 2 & 2.3 & 2 & 2.3 & 4 & 4.5 & 0.638 \\
\hline Lengkap & 32 & 36.4 & 52 & 59.1 & 84 & 95.5 & \\
\hline Total & 34 & 38.6 & 54 & 61.4 & 88 & 100.0 & \\
\hline
\end{tabular}

Status gizi balita menurut BB/U yang mempunyai status gizi yang kurang sebesar 18 (20.5\%) balita. Bagi balita yang mempunyai status gizi yang kurang yang memiliki penyakit infeksi sebesar 8 (9.1\%) dan sebesar 10 (11.4\%) balita yang mendapatkan status gizi yang kurang yang tidak mempunyai penyakit infeksi. Status gizi balita yang baik $70(79.5 \%)$ balita. Bagi balita yang mendapatkan status gizi kurang yang mempunyai penyakit infeksi sebesar 18 (20.5\%) dan sebesar 52 (59.1\%) balita yang mendapatkan status gizi yang baik yang tidak ditemukan adanya penyakit infeksi. Berdasarkan hasil penelitianini mendapati bahwa $p$ value $=0.206$, sehingga dari penelitian ini mendapati bahwa tidak adanya hubungan penyakit infeksi dengan status gizi berdasarkan BB/U (Tabel 9). 
Tabel 8. Hubungan riwayat pemberian imunisasi dengan status gizi balita berdasarkan $\mathrm{BB} / \mathrm{TB}$

\begin{tabular}{|c|c|c|c|c|c|c|c|}
\hline \multirow{3}{*}{$\begin{array}{l}\text { Imuni- } \\
\text { sasi }\end{array}$} & \multicolumn{4}{|c|}{$\begin{array}{c}\text { Status gizi balita } \\
\text { BB/TB }\end{array}$} & \multirow{2}{*}{\multicolumn{2}{|c|}{ Total }} & \multirow{3}{*}{$\begin{array}{c}p \\
\text { value }\end{array}$} \\
\hline & \multicolumn{2}{|c|}{ Pendek } & \multicolumn{2}{|c|}{ Normal } & & & \\
\hline & $\mathrm{N}$ & $\%$ & $\mathrm{~N}$ & $\%$ & $\mathrm{~N}$ & $\%$ & \\
\hline $\begin{array}{l}\text { Tidak } \\
\text { Lengkap }\end{array}$ & 0 & 0.0 & 4 & 4.5 & 4 & 4.5 & \multirow[t]{2}{*}{1.000} \\
\hline Lengkap & 6 & 6.8 & 78 & 88.6 & 84 & 95.5 & \\
\hline Total & 6 & 6.8 & 82 & 93.2 & 88 & 100.0 & \\
\hline
\end{tabular}

${ }^{\star}$ Fisher's Exact Test

Tabel 9. Hubungan penyakit infeksi dengan status gizi balita berdasarkan $\mathrm{BB} / \mathrm{U}$

\begin{tabular}{|c|c|c|c|c|c|c|c|}
\hline \multirow{4}{*}{$\begin{array}{l}\text { Penyakit } \\
\text { Infeksi }\end{array}$} & \multirow{2}{*}{\multicolumn{4}{|c|}{$\begin{array}{c}\text { Status gizi balita } \\
\mathrm{BB} / \mathrm{U}\end{array}$}} & \multirow{3}{*}{\multicolumn{2}{|c|}{ Total }} & \multirow{4}{*}{$\begin{array}{c}p \\
\text { value }\end{array}$} \\
\hline & & & & & & & \\
\hline & \multicolumn{2}{|c|}{$\begin{array}{c}\text { Gizi } \\
\text { Kurang }\end{array}$} & \multicolumn{2}{|c|}{ Gizi Baik } & & & \\
\hline & $\mathrm{N}$ & $\%$ & $\mathrm{~N}$ & $\%$ & $N$ & $\%$ & \\
\hline $\mathrm{Ya}$ & 8 & 9.1 & 18 & 20.5 & 26 & 29.5 & 0.206 \\
\hline Tidak & 10 & 11.4 & 52 & 59.1 & 62 & 70.5 & \\
\hline Total & 18 & 20.5 & 70 & 79.5 & 881 & 100.0 & \\
\hline
\end{tabular}

Status gizi balita menurut TB/U yang mempunyai status gizi yang pendek sebesar 34 (38.6\%) balita. Bagi balita yang mempunyai status gizi pendek yang menderita penyakit infeksi sebesar 11 (12.5\%) dan 23 (26.1\%) balita yang mempunyai status gizi pendek yang tidak ditemukan adanya penyakit infeks. Status gizi balita yang normal 54 (61.4\%). Bagi balita yang mempunyai status gizi yang normal yang menderita penyakit infeksi sebesar $52(59.1 \%)$ dan $2(2.3 \%)$ balita yang mempunyai status gizi yang normal yang tidak ditemukan adanya penyakit infeks. Berdasarkan hasil penelitian ini menyatakan $p$ value $=0.638$, sehingga dari penelitian ini menyatakan bahwa tidak adanya hubungan antara hubungan antara penyakit infeksi dengan status gizi berdasarkan TB/U (Tabel 10).

Tabel. 10 Hubungan Penyakit Infeksi Dengan Status Gizi Balita berdasarkan TB/U

\begin{tabular}{|c|c|c|c|c|c|c|c|}
\hline \multirow{4}{*}{$\begin{array}{l}\text { Penyakit } \\
\text { Infeksi }\end{array}$} & \multicolumn{6}{|c|}{ Status gizi balita } & \multirow{4}{*}{$\begin{array}{c}p \\
\text { value }\end{array}$} \\
\hline & & & $\mathrm{B} / \mathrm{U}$ & & \multirow{2}{*}{\multicolumn{2}{|c|}{ Total }} & \\
\hline & \multicolumn{2}{|c|}{ Pendek } & \multicolumn{2}{|c|}{ Normal } & & & \\
\hline & $\mathrm{N}$ & $\%$ & $\mathrm{~N}$ & $\%$ & $\mathrm{~N}$ & $\%$ & \\
\hline $\mathrm{Ya}$ & 11 & 12.5 & 15 & 17.0 & 26 & 29.5 & 0.0 \\
\hline Tidak & 23 & 26.1 & 39 & 44.3 & 62 & 70.5 & \\
\hline Total & 34 & 38.6 & 54 & 61.4 & 88 & 100.0 & \\
\hline
\end{tabular}

Gizi balita menurut BB/TB yang mendapatkan status gizi kurus sebanyak $6(6.8 \%)$ balita. Bagi balita yang mempunyai status gizi yang kurus yang mendapatkan penyakit infeksi sbanyak 1 (1.1\%) dan sebanyak 5 $(5.7 \%)$ balita mempunyai status gizi yang kurus yang tidak ditemukan adanya penyakit infeksi (Tabel 11).

Tabel. 11 Hubungan penyakit infeksi dengan status gizi balita berdasarkan $\mathrm{BB} / \mathrm{TB}$

\begin{tabular}{|c|c|c|c|c|c|c|}
\hline \multirow{4}{*}{$\begin{array}{l}\text { Penyakit } \\
\text { Infeksi }\end{array}$} & \multicolumn{6}{|c|}{ Status gizi balita } \\
\hline & \multicolumn{4}{|c|}{$\mathrm{B} \quad \mathrm{BB} / \mathrm{TB}$} & \multirow{2}{*}{ Total } & \multirow{3}{*}{$\begin{array}{c}p \\
\text { value }\end{array}$} \\
\hline & \multicolumn{2}{|c|}{ Kurus } & \multicolumn{2}{|c|}{ Normal } & & \\
\hline & $\mathrm{N}$ & $\%$ & $\mathrm{~N}$ & $\%$ & $\%$ & \\
\hline $\mathrm{Ya}$ & 1 & 1.1 & 25 & 28.4 & 2629.5 & 0.665 \\
\hline Tidak & 5 & 5.7 & 57 & 64.8 & 6270.5 & \\
\hline Total & 6 & 6.8 & 82 & 93.2 & 88100.0 & \\
\hline
\end{tabular}

${ }^{*}$ Fisher's Exact Test

Status gizi balita yang normal sebanyak $82(93.2 \%)$ balita. Bagi balita yang mempunyai status gizi yang normal yang mendapatkan penyakit infeksi sebanyak 25 (28.4\%) dan 57 
(64.8\%) balita mempunyai status gizi yang normal yang tidak ditemukan adanya penyakit infeksi. Berdasarkan hasil dari penelitian ini menyatakan $p=$ value 0.665 , sehingga dari penelitian ini menyatakan bahwa tidak adanya hubungan penyakit infeksi dengan status gizi berdasarkan BB/TB.

\section{PEMBAHASAN}

\section{Karakteristik Responden Penelitian}

Masalah gizi pada anak lebih banyak terdapat pada kelompok responden dengan pendidikan tamat SMA, DIII, dan SI dari pada responden yang memiliki pendidikan dibawahnya. Kelompok responden dengan pendidikan SMA, DIII dan SI juga memiliki jumlah anak yang berstatus gizi normal dibandingkan jenjang pendidikan dibawahnya. Balita yang memiliki masalah gizi berasal dari kelompok ibu yang tidak bekerja dari pada ibu yang bekerja, sekaligus kelompok balita yang memiliki status gizi normal juga berasal dari kelompok ibu yang tidak bekerja.

\section{Status Gizi}

Terdapat 34 (38.6\%) balita yang memiliki status gizi yang pendek, 54 $(61.4 \%)$ balita memiliki status gizi yang normal. Indeks status gizi BB/U terdapat $18(20.5 \%)$ balita memiliki status gizi yang dikategorikan gizi kurang, 70 $(79.5 \%)$ balita memiliki status gizi yang dikategorikan gizi baik. Indeks status gizi BB/TB terdapat $6(6.8 \%)$ balita memiliki status gizi yang dikategorikan kurus dan $82(93.2 \%)$ balita memiliki status gizi yang dikategorikan normal. Hasil penelitian Sinaga (2014), didapati bahwa balita yang berstatus gizi pendek berjumlah 38 (62.3\%) dan 13 (21.3\%) memiliki status gizi normal. Indeks status gizi berdasarkan $\mathrm{BB} / \mathrm{U}$ yang memiliki status gizi kurang berjumlah 5 $(8.2 \%)$ balita dan 56 (91.8\%) balita memiliki status gizi baik.

Hasil penelitian Cristina (2017) distribusi status gizi balita berdasarkan BB/U menunjukan terdapat 24 balita
$(23,8 \%)$ memiliki status gizi kurang dan 77 balita $(76,2 \%)$ memiliki status gizi baik. Distribusi status gizi balita berdasarkan TB/U menunjukan terdapat 1 balita (1,0\%) memiliki status gizi sangat pendek, 25 balita $(24,7 \%)$ memiliki status gizi pendek, dan 75 balita $(74,3 \%)$ memiliki status gizi normal. Distribusi status gizi balita berdasarkan $\mathrm{BB} / \mathrm{TB}$ menunjukan balita $(2,0 \%)$ memiliki status gizi sangat kurus, 8 balita $(7,9 \%)$ memiliki status gizi kurus dan 91 balita (74,3\%) memiliki status gizi normal.

\section{Hubungan antara Riwayat Pemberian Imunisasi dengan Status Gizi (BB/U)}

Hasil penelitian ini didapatkan bahwa riwayat pemberian imunisasi yang lengkap $76.1 \%$ yang memiliki gizi baik dan $19.3 \%$ yang memiliki gizi kurang. Tidak mendapat imunisasi lengkap 3.4\% yang memiliki gizi baik dan $.1 .1 \%$ yang memiliki gizi kurang. Dari hasil uji statistik didapatkan $\mathrm{p}$ value 1.000, sehingga tidak terdapat hubungan yang bermakna antara riwayat pemberian imunisasi dengan status gizi berdasarkan BB/U.

Berbeda dengan hasil penelitian yang dilakukan oleh Vindriana (2012) di kelurahan Watonea wilayah kerja Puskesmas Katobu Kabupaten Muna, dimana terdapat hubungan yang bermakna antara kelengkapan imunisasi dengan status gizi, diperoleh nilai $p=$ 0,000 yang berarti lebih kecil dari nilai $\alpha$ $(0,05)$. Faktor ibu sangat berperan nyata dalam menentukan status gizi anak. Menurunnya status gizi pada anak dapat disebabkan oleh munculnya penyakit infeksi pada anak, status ekonomi yang kurang dan pola asuh orang tua yang tidak baik.

\section{Hubungan antara Riwayat Pemberian Imunisasi dengan Status Gizi (TB/U)}

Hasil penelitian ini didapatkan bahwa balita yang memiliki status gizi normal yang mendapatkan imunisasi lengkap berjumlah $59.1 \%$ dan $36.4 \%$ yang memiliki status gizi pendek. Balita yang memiliki status gizi pendek yang 
mendapat imunisasi lengkap berjumlah $2.3 \%$ dan $2.3 \%$ balita yang memiliki status gizi normal. Hasil uji statistik didapatkan $p$ value 0.638 , sehingga tidak terdapat hubungan yang bermakna antara pemberian imunisasi dengan status gizi berdasarkan TB/U. Sejalan dengan penelitian yang dilakukan oleh Gaol (2016) di Wilayah Kerja Puskesmas Kombos, dimana tidak terdapat hubungan antara pemberian imunisasi dengan status gizi, diperoleh nilai $p=0.945$ yang berarti lebih besar dari $\alpha(0.05)$.

Menurut Sastroasmoro (2007) upaya untuk memperoleh kekebalan dalam hal ini kekebalan terhadap penyakit infeksi adalah dengan melakukan imunisasi. Imunisasi dalam sistem kesehatan nasional adalah salah satu bentuk intervensi kesehatan yang sangat efektif dalam upaya menurunkan angka kematian balita. Faktor pendidikan dari ibu dapat menentukan baik tidaknya pertumbuhan dari anak tersebut.

\section{Hubungan antara Riwayat Pemberian Imunisasi dengan Status Gizi (BB/TB)}

Hasil penelitian ini didapatkan bahwa balita yang memiliki status gizi normal dan mendapatkan imunisasi lengkap berjumlah $88.6 \%$ dan $6.8 \%$ balita yang memiliki status gizi kurus. Balita yang memiliki status gizi normal dan tidak mendapat imunisasi lengkap berjumlah $4.5 \%$ dan $0.0 \%$ balita yang memiliki status gizi kurus. Hasil uji statistik didapatkan nilai $p$ value 1.000 , sehingga tidak terdapat hubungan yang bermakna antara riwayat pemberian imunisasi dengan status gizi berdasarkan BB/TB.

Berbeda dengan penelitian yang dilakukan oleh Gaol (2016) di Wilayah Kerja Puskesmas Kombos, dimana terdapat hubungan antara pemberian imunisasi dengan status gizi berdasarkan BB/TB, diperoleh nilai $p=0.016$ yang berarti lebih kecil dari $\alpha=0.05$. Pendapat Erwin (2015) menyebutkan bahwa dengan melakukan imunisasi kepada balita, tidak hanya memberikan perlindungan pada anak tersebut tetapi juga berdampak kepada anak lainnya, karena terjadi tingkat imunitas umum yang meningkat dan mengurangi penyebaran infeksi

\section{Hubungan antara Penyakit Infeksi dengan status gizi $\mathrm{BB} / \mathrm{U}$}

Balita yang mengalami penyakit infeksi dan memiliki status gizi yang baik berjumlah $20,7 \%$ dan $5,3 \%$ yang memiliki status gizi kurang. Balita yang tidak mengalami penyakit infeksi dan memiliki status gizi baik berjumlah $49,3 \%$ dan $12,7 \%$ yang memiliki gizi kurang. Hasil uji statistik didapatkan $p$ value 0.206 , sehingga tidak terdapat hubungan yang bermakna antara penyakit infeksi dengan status gizi $\mathrm{BB} / \mathrm{U}$.

Sejalan dengan penelitian yang dilakukan oleh Putri (2015) di Desa Mopusi Kecamatan Loloyan Kabupaten Bolaang Mongondow Induk, dimana tidak terdapat hubungan antara penyekit infeksi dengan status gizi BB/ $U$, diperoleh nilai $p=0.268$ yang berarti lebih besar dari $\alpha=0.05$. Berbeda dengan penelitian yang dilakukan oleh Dirgantara (2017) di Kecamatan Kelapa Lima Kota Kupang dimana $p$ value 0.024 yang berarti lebih kecil dari $\alpha=0.05$, dari hasil penelitian Dirgantara Dikatakan bahwa penyakit infeksi sangat berpengaruh terhadap status gizi anak dikarenakan adanya penurunan nafsu makan. Pola makan yang salah, pola asuh anak berpengaruh pada timbulnya kurang gizi/penyakit infeksi. Anak yang diasuh ibunya sendiri dengan kasih sayang, apalagi ibunya berpendidikan, manfaat pelayanan kesehatan, pentingnya ASI pada anak dan sanitasi lingkungan yang bersih dapat menjadi faktor utama agar anak tidak mendapat penyakit infeksi.

\section{Hubungan antara Penyakit Infeksi dengan Status Gizi TB/U}

Status gizi normal dan mengalami penyakit infeksi berjumlah $17,0 \%$ dan $12.5 \%$ balita yang memiki status gizi 
pendek. Balita yang tidak mengalami penyakit infeksi $44.3 \%$ yang memiliki status gizi normal dan $26.1 \%$ yang memiliki status gizi pendek. Dari hasil uji statistik didapatkan nilai $p$ value 0.827 , sehingga tidak terdapat hubungan yang bermakna antara penyakit infeksi dengan status gizi TB/U.

Hasil penelitian ini sejalan dengan penelitian yang dilakukan oleh Gaol (2016) di wilayah kerja Puskesmas Kombos Kota Manado, dimana tidak terdapat hubungan yang bermakna antara penyakit infeksi dengan status gizi $T B / U$, diperoleh nilai $p=0.270$ yang berarti lebih besar dari $\alpha=0.05$.

Sejalan juga dengan penelitian yang dilakukan oleh Putri (2016) di Desa Mopusi Kecamatan Loloyan Kabupaten Bolaang Mongondow Induk, dimana tidak terdapat hubungan antara penyakit infeksi dengan status gizi $T B / U$, diperoleh nilai $p=0.580$ yang berarti lebih besar dari $\alpha=0.05$. Gizi mempunyai peran sangat penting dalam pemeliharaan kesehatan tubuh balita. Jika balita mengalami status gizi kurang maka akan mempermudah kumankuman patogen menyerang tubuh sehingga terjadi infeksi. Maka dari itu untuk mengurangi angka kejadian penyakit infeksi maka status gizi balita harus selalu dijaga dan ditingkatkan.

\section{Hubungan Antara Penyakit Infeksi Dengan Status Gizi BB/TB}

Balita yang mengalami penyakit infeksi dan memiliki status gizi normal berjumlah $28.4 \%$ dan $1.1 \%$ balita yang memiliki status gizi kurus. Balita yang tidak mengalami penyakit infeksi memilki status gizi normal berjumlah $64,8 \%$ dan $5.7 \%$ yang memiliki status gizi kurus. Dari hasil uji statistik didapatkan $p$ value 0.665 , sehingga tidak terdapat hubungan yang bermakna antara penyakit infeksi dengan status gizi BB/TB.
Hasil penelitian ini sejalan dengan penelitian yang dilakukan oleh Gaol (2016) di wilayah kerja Puskesmas Kombos Kota Manado, dimana tidak terdapat hubungan yang bermakna antara penyakit infeksi dengan status gizi $B B / T B$, diperoleh nilai $p=0.348$ yang berarti lebih besar dari $\alpha=0.05$. Sejalan juga dengan hasil penelitian yang dilakukan oleh Putri (2016) di Desa Mopusi Kecamatan Loloyan Kabupaten Bolaang Mongondow Induk, dimana tidak terdapat hubungan yang bermakna antara penyekit infeksi dengan status gizi (BB/TB), diperoleh nilai $p=0.372$ yang berarti lebih besar dari $\alpha=0.05$.

Berbeda dengan penelitian yang dilakukan oleh Handayani (2017) di Wilayah Kerja Puskesmas Seberang Padang, dimana terdapat hubungan antara penyakit infeksi dengan status gizi. Dari hasil uji statistik didapatkan nilai $p=0.001$ yang berarti lebih kecil dari $\alpha=0.05$. Menurut Rahmawati (2008), semakin baik status gizi balita maka semakin besar peluang tidak menderita penyakit infeksi. Status gizi yang baik umumnya akan meningkatkan resistensi tubuh terhadap penyakit-penyakit infeksi. Faktor utama timbulnya penyakit infeksi yaitu seperti kondisi lingkungan yang buruk dan status imunitas yang rendah. Lingkungan didalam rumah yang penuh dengan asap rokok juga menyebabkan anak lebih mudah terserang penyakit infeksi saluran pernafasan. Status imunitas rendah selain memudahkan anak terserang infeksi juga menyebabkan durasi penyakit infeksi menjadi lama.

\section{KESIMPULAN}

Hasil penelitian menunjukan bahwa tidak adanya hubungan antara riwayat pemberian imunisasi dengan status gizi anak usia 24-59 bulan menurut indeks antropometri $\mathrm{BB} / \mathrm{U}$, $T B / U$ dan BB/TB. Hubungan antara penyakit infeksi dengan status gizi anak usia 24-59 bulan menurut indeks antropometri BB/U, TB/U dan BB/TB tidak terdapat hubungan. 


\section{DAFTAR PUSTAKA}

Anonim (2016) Profil kesehatan Kabupaten Minahasa Tengqara..

Cristina R (2017) Faktor-faktor yang berhubungan dengan pemberian imunisasi BCG dan DPT pada Bayi di Posyandu Beo diwilayah keria Puskesmas Batahan Kabupaten Mandailing Natal, Sumatera Utara.

Dirgantara A (2017) Hubungan riwayat penyakit infeksi dan pemberian ASI eksklusif dengan status gizi anak usia 7-12 bulan di Kecamatan Kelapa Lima, Kupang..

Erwin H (2015) Hubungan pemberian ASI dan imunisasi dengan status gizi anak 0-23 bulan di Pulau Sulawesi.

Gaol KL (2016) Faktor-faktor yang berhubungan dengan status gizi anak balita di wilayah kerja Puskesmas Kombos, Manado

Gerungan GP (2014) Hubungan antara riwayat penyakit infeksi dengan kejadian stunting pada anak usia 13-36 bulan di wilayah kerja Puskesmas Tuminting, Manado.

Handayani R (2017) Faktor - faktor yang berhubungan dengan status gizi pada anak Balita. Padang.

Kementerian Kesehatan Rl (2015) Rencana strategis kementerian kesehatan tahun 2015-2019.

Kementerian Kesehatan RI (2016) Situasi Balita Pendek 2016.

Kementrin kesehatan RI (2017) Data dan informasi profil kesehatan Indonesia 2017

Putri RF (2015) Faktor-faktor yang berhubungan dengan status gizi anak balita di Wilayah Kerja Puskesmas Nanggalo, Padang.
Riset kesehatan dasar (RISKESDAS) (2013) Badan penelitian dan pengembangan kesehatan kementrian kesehatan RI.

Sinaga P (2014) Hubungan status gizi dan status imunisasi dengan kejadian infeksi Saluran Pernapasan Akut (ISPA) pada balita di wilayah kerja puskesmas Soposurung Kecamatan Balige Kabupaten Toba Samosir.

Sastroasmoro S. 2007. Membina tumbuh kembang bayi dan balita. ikatan dokter anak Indonesia, Jakarta.

Syukriawati R (2011) Faktor-faktor yang berhubungan dengan status gizi kurang pada anak usia 24-59 bulan di Kelurahan Pamulang Barat Kota Tangerang Selatan Tahun 2011. Program Studi KesMas Fakultas Kedokteran dan IImu Kesehatan UIN Syarif Hidayatullah, Jakarta.

Susiloningrum WT (2017) Hubungan pengetahuan ibu dan status imunisasi dengan status gizi balita 2-3 tahun. Surakarta.

Vindriana V (2015) Hubungan kelengkapan imunisasi dengan status gizi pada balita usia 1-5 tahun Di Kelurahan Watonea Wilayah Kerja Puskesmas Katobu Kabupaten Muna.

WHO (2010) Nutrition Landscape Information System (NLIS) Country Profile Indicators. 